\title{
INCREASED CALCIUM 45 FLUXES IN HISTOLOGICALLY ABNORMAL HUMAN ASCENDING AORTA
}

\author{
J. H. Kennedy, MD, ${ }^{\mathrm{a}}$ D. Henrion, PhD, ${ }^{\mathrm{b}}$ M. Wassef, MD, ${ }^{\mathrm{c}}$ A. Piwnica, MD, ${ }^{\mathrm{d}}$ G. Bloch, MD, ${ }^{\mathrm{d}}$ and A. Tedgui, PhD, ${ }^{\mathrm{b}}$ \\ Paris, France, and Cambridge, United Kingdom
}

Vascular calcium overload occurs during aging and is accelerated by severe diabetes, smoking, and hypertension, ${ }^{1}$ associated with vascular structural changes such as coronary artery calcification. ${ }^{2}$ We hypothesize that these vascular structural changes might be associated with change(s) in calcium turnover, which might lead to vascular disorders irrespective of age. We therefore studied, in vitro, the flux of ${ }^{45} \mathrm{Ca}^{2+}$ in ascending aortic wall obtained from 27 patients aged 7 to 84 years, mean 54.6 (nine women), undergoing aortic valve replacement. No consent other than that for anesthesia and surgery was obtained. Ascending aortic wall was removed from the aortotomy; part was fixed in Bouin's solution and embedded in paraffin. Then $4 \mu \mathrm{m}$ sections stained with Masson's trichrome stain were evaluated without knowledge of $\mathrm{Ca}^{2+}$ flux. Adventitia-free aortic segments were bathed in physiologic saline solution containing ${ }^{45} \mathrm{Ca}^{2+}(296 \mathrm{kBq} /$ $\mathrm{ml}$ ) for 120 minutes at room temperature to label the exchangeable $\mathrm{Ca}^{2+}$, according to the mehtod of Meisheri, Hwang, and van Breemen. ${ }^{3}$ Tissues were transferred to ice-cold $\mathrm{Ca}^{2+}$-free physiologic saline solution for $30 \mathrm{~min}$ utes to remove extracellular ${ }^{45} \mathrm{Ca}^{2+} .4$ They were then incubated overnight in ethylenediaminetetraacetic acid (2 $\mathrm{mmol} / \mathrm{L}$ ) at room temperature. Tissue and effluent were analyzed for ${ }^{45} \mathrm{Ca}^{2+}$ in a liquid scintillation counter. ${ }^{45} \mathrm{Ca}^{2+}$ net uptake is expressed as nanomoles per milligram weight. The ratio of ${ }^{45} \mathrm{Ca}^{2+}$ total uptake by the tissue to ${ }^{45} \mathrm{Ca}^{2+}$ concentration in the incubating bath, the distribution volume, was calculated. ${ }^{45} \mathrm{Ca}^{2+}$ efflux was expressed as percent total efflux, and efflux rate constant (per minute) was calculated from the total counts lost from the tissue during each washout period divided by the total counts remaining in the tissue segment. ${ }^{4}$ Results were expressed as means \pm standard error. The significance of the differences between means was determined by the Student's $t$ test (A. Tedgui).

Histologic findings in nine patients aged 26 to 83 years (mean 61.9 years) were "normal for age"5 (Fig. 1). In 18

From INSERM U 141, ${ }^{\mathrm{b}}$ Service Central D'Anatomie et Cytologie Pathologiques, ${ }^{\mathrm{c}}$ Service de Chirurgie Cardio-vasculaire, IFR "Circulation Lariboisiere," Hopital Lariboisiere, Paris, France, and The Babraham Institute, ${ }^{\mathrm{a}}$ Cambridge, United Kingdom.

Received for publication March 10, 1997; accepted for publication August 8, 1997.

Address for reprints: J. H. Kennedy, MD, The Babraham Institute, Cambridge CB2 4AT, United Kingdom.

J Thorac Cardiovasc Surg 1998;115:238-9

Copyright (c) 1998 by Mosby, Inc.

$0022-5223 / 98 \$ 5.00+0 \quad \mathbf{1 2 / 5 4 / 8 5 3 7 3}$ patients aged 7 to 86 years (mean 52.9 years) histologic findings were considered abnormal (Fig. 2). The net uptake of ${ }^{45} \mathrm{Ca}^{2+}$ was significantly higher in samples of ascending aorta histologically abnormal than in those histologically normal for age: $365 \pm 36.8 \mathrm{nmol} / \mathrm{mg}$ tissue $(n=18)$ versus $244 \pm 37 \mathrm{nmol} / \mathrm{mg}$ tissue $(n=9, p<0.05)$. The distribution volume for calcium in histologically abnormal tissue was significantly greater than in tissues normal for age: $2.4 \pm 0.27(n=18)$ versus $1.9 \pm 0.27(n=$ $9, p<0.05)$. Efflux of ${ }^{45} \mathrm{Ca}^{2+}$ from the ascending aorta as percent of total as a function of time was $32.6 \% \pm 4.5 \%$ $(n=18)$ versus $17.8 \% \pm 3.5 \%(n=9, p<0.04)$ at 1 and 2 minutes. ${ }^{45} \mathrm{Ca}^{2+}$ efflux rate constant was significantly

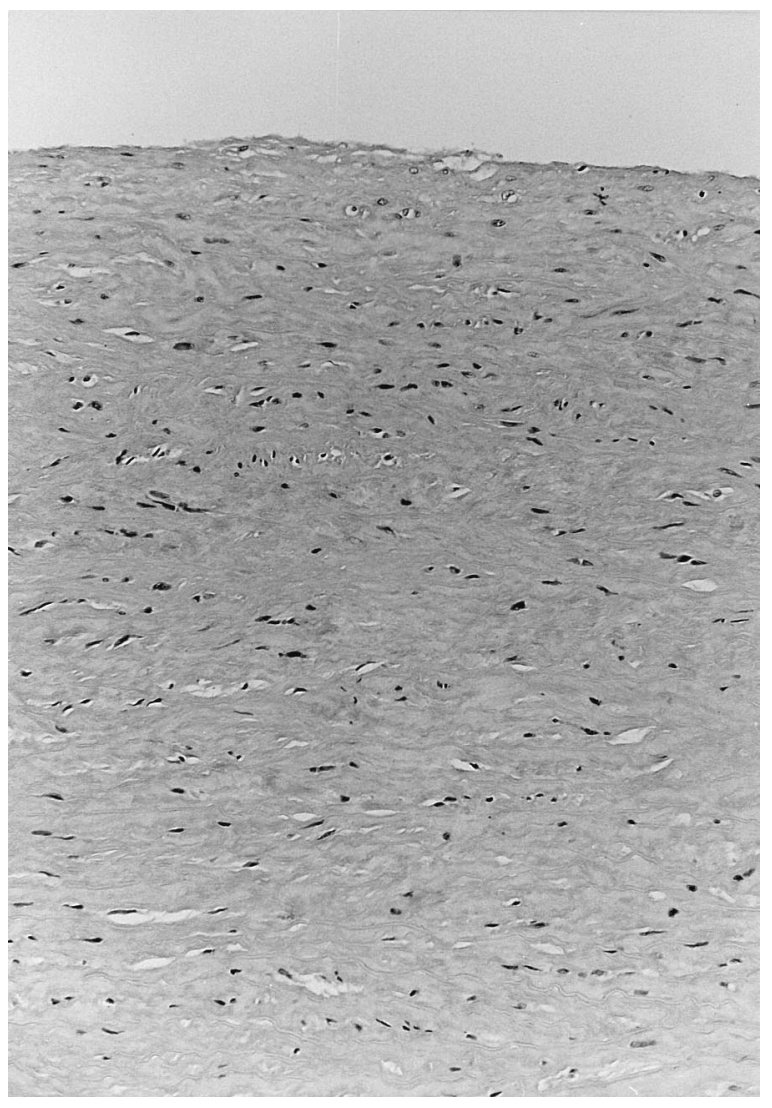

Fig. 1. Aorta, normal for age from a patient aged 76 years, showing mild initimal thickening and moderate fibrosis of the media (Masson's trichrome stain; original magnification $\times 160)$. 


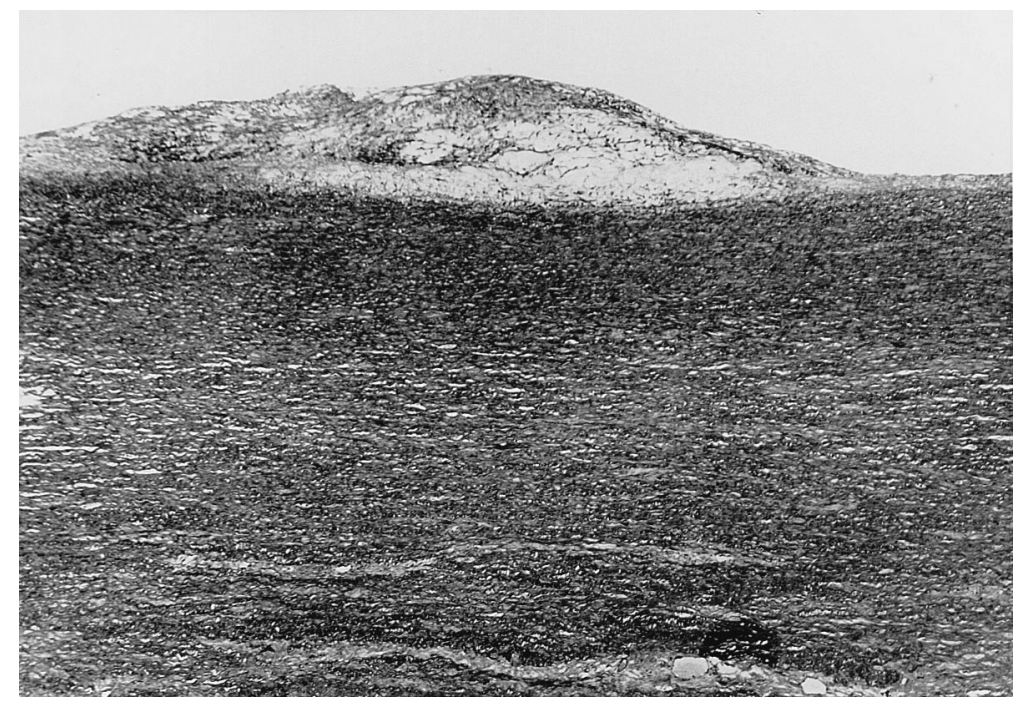

Fig. 2. Aorta, showing atheroma (Masson's trichrome stain; original magnification $\times 40$ ).

increased in histologically abnormal tissue: $0.3 \pm 0.06$ $\min ^{-1}(n=18)$ versus $0.14 \pm 0.06 \min ^{-1}(n=9, p<0.05)$.

Our study agrees with previous observations that atherosclerotic human aorta binds more calcium in vivo than normal tissue. ${ }^{5}{ }^{45} \mathrm{Ca}^{2+}$ net uptake is an equilibrium between influx and efflux of $\mathrm{Ca}^{2+}$ in the arterial wall cells, ${ }^{3}$ whereas volume distribution represents the ratio of uptake by the tissue to ${ }^{45} \mathrm{Ca}^{2+}$ concentration in the incubating bath, corresponding to the accumulation of $\mathrm{Ca}^{2+}$ in the arterial wall, including cells and matrix. That ${ }^{45} \mathrm{Ca}^{2+}$ net uptake was increased in tissues with abnormal histologic characteristics suggests an increased accumulation in cells, without excluding an increased accumulation in the extracellular matrix, which would be responsible at least in part for the increased distribution volume. ${ }^{45} \mathrm{Ca}^{2+}$ efflux can be divided into two phases. The initial loss of ${ }^{45} \mathrm{Ca}^{2+}$ represents mainly the washout of extracellular ${ }^{45} \mathrm{Ca}^{2+}$. Efflux of ${ }^{45} \mathrm{Ca}^{2+}$ occurring thereafter represents loss from intracellular sources. The increase in ${ }^{45} \mathrm{Ca}^{2+}$ efflux in tissues with abnormal histologic features and the increased ${ }^{45} \mathrm{Ca}^{2+}$ net uptake suggests an increased $\mathrm{Ca}^{2+}$ turnover in vessel wall. Change in $\mathrm{Ca}^{2+}$ homeostasis leads to vascular disorders by structural change, as observed in postmortem human aorta.

Our results suggest that histologically abnormal human ascending aorta is associated with binding of $\mathrm{Ca}^{2+}$ irrespective of age.

We thank Professor Philippe Menasché for his assistance in this study.

\section{REFERENCES}

1. Fleckenstein A, Fleckenstein-Grun G, Frey M, Zorn J. Calcium antagonism and ACE inhibition. Am J Hypertens 1989; 2:194-204.

2. Fitzpatrick LA, Severson A, Edwards WD, Ingraham RT. Diffuse calcification in human coronary arteries. J Clin Invest 1994;94:1597-604.

3. Meisheri KD, Hwang O, van Breemen C. Evidence for two separated $\mathrm{Ca}^{2+}$ pathways in smooth muscle plasmalemma. J Membrane Biol 1981;59:19-25.

4. Henrion D, Bevan JA. Intraluminal flow preferentially increases net sodium uptake in rabbit facial vein. J Vasc Res 1995;32:413-22.

5. Bouissou H, Pieraggi MT, Julian M. Age related morphological changes of the arterial wall. In: Camilleri JP, Berry CL, Fiessinger JN, Bariety J, editors. Diseases of the arterial wall. London: Springer Verlag; 1989. p. 77-8. 